\title{
PEMBELAJARAN KOSAKATA BAHASA INGGRIS MELALUI PERMAINAN SCRABBLE
}

\author{
Desi Sri Astuti ${ }^{1}$, Muhammad Iqbal Ripo Putra ${ }^{2}$, Senny Wiyanti ${ }^{3}$, Rodhi ${ }^{4}$, \\ Dian Shinta Sari ${ }^{5}$ \\ 1,2,3,4,5 Program Studi Pendidikan Bahasa Inggris, Fakultas Pendidikan Bahasa dan Seni \\ IKIP PGRI Pontianak, Jalan Ampera No.88 Pontianak \\ 1e-mail: desisa28@gmail.com
}

\begin{abstract}
Abstrak
Tujuan dari kegiatan pengabdian masyarakat ini adalah pendampingan siswa dengan menerapkan permainan papan scrabble dalam pembelajaran di kelas dan menghasilkan kosakata Bahasa Inggris yang baru bagi siswa. Kegiatan ini dilakukan di salah satu sekolah madrasah yang berada di Pontianak. Target Pesertanya adalah siswa kelas VIII. Metode yang digunakan adalah metode teori dan praktik. Hasil yang diperoleh melalui pelatihan ini adalah pengetahuan pembelajaran inovatif dengan permainan scrabble dan kemampuan peserta didik mengimplementasikan permainan scrabble untuk menambah kosakata Bahasa Inggris.
\end{abstract}

Kata Kunci: pendampingan, scrabble, kosakata

\begin{abstract}
The purpose of this community service activity is to assist students by implementing scrabble board games in classroom learning and producing new English vocabulary for students. This activity carried out at one of the Islamic schools in Pontianak. The eight grader students involved as participant. The theory and practice approach were deployed to collect the information of students' enthusiasm. The results obtained through this training are innovative learning knowledge with scrabble games and the ability of students to implement scrabble games to add English vocabulary.
\end{abstract}

Keywords: assisting, scrabble, vocabulary

\section{PENDAHULUAN}

Pembelajaran dalam di sekolah mengacu pada Kurikulum yang telah ditetapkan pemerintah dimana tertuang dalam silabus pendidikan pada setiap jenjang pendidikan. Tidak terkecuali untuk tingkat Sekolah Menengah Pertama, dimana pada setiap akhir semester siswa diharuskan untuk menuntaskan mata pelajaran yang ada seperti halnya mata pelajaran Bahasa inggris dimana siswa dinyatakan tuntas ketika sudah memenuhi Kriteria Ketuntasan Minimum (KKM) yang ditetapkan di setiap sekolah.

Siswa dikatakan mahir berbahasa inggris ketika sudah dapat menguasi aspek 
keterampilan berbahasa inggris yang terdiri dari membaca, menulis, mendengarkan dan berbicara. Agar menguasi keempat aspek tersebut, diperlukan penguasaan kosakata yang lebih banyak sehingga dapat dengan mudah belajar bahasa inggris baik tulis maupun lisan. Belajar kosakata dengan cara intensitas tinggi sangat berguna bagi peserta didik, dan karenanya harus ditangani secara eksplisit. Kosakata akademik layak difokuskan pada pelajar yang ingin belajar dalam bahasa Inggris, dan hal yang sama berlaku untuk kosakata teknis bagi pelajar yang berfokus pada ranah tujuan khusus (Felder \& Prince, 2000; Mukoroli, 2011; Schmitt \& Schmitt, 2014). Semakin banyak kosakata yang dimiliki seseorang, maka semakin mudah seseorang tersebut berkomunikasi dengan orang lain. Hal ini menggambarkan bahwa kosakata penting dalam kehidupan sehari-hari.

Dalam keterkaitan tujuan dan usaha yang bisa dilakukan untuk mengatasi berbagai hambatan dalam belajar bahasa Inggris terutama dalam hal pelafalan yang jarang diajarkan dengan spesifik di sekolah pada saat belajar. Maka perlu diberikan latihan dan pembimbingan kepada para siswa dalam mengembangkan pemahaman siswa dan peningkatan kompetensi berkomunikasi dalam bentuk lisan dan mempunyai kepercayaan diri dalam mengaplikasinya dalam belajar berbicara. Dalam peningkatan ketrampilan berbicara, pelafalan sebuah kata yang tepat merupakan suatu kemutlakan. Dalam berkomunikasi, seseorang perlu memastikan bahwa dia bisa melafalkan kata dengan tepat agar terjadi komunikasi yang harmonis, saling memahami apa yang diucapkan dan tidak menimbulkan kesalahpahaman dan salah interprestasi. Penyebab utama kesalahan dalam pelafalan bahasa Inggris adalah perbedaan antara ucapan dan tulisan.

Ketidakkonsistenan antara keduanya dan kurangnya latihan dalam melafalkannnya menyebabkan kesulitan dalam pelafalan dan komunikasi yang baik dalam bahasa Inggris. Kompetensi pembelajaran di sekolah dalam hal pelafalan kosakata bahasa Inggris kurang mendapatkan perhatian khusus, sehingga menyebabkan komunikasi yang terbatas karena faktor takut salah. Selanjutnya dalam meningkatkan kompetensi berkomunikasi baik dalam lisan maupun tulisan, maka setiap orang perlu memperluas kosakata, perlu mengetahui 
sebanyak-banyakanya perbendaharaan kata dalam bahasanya (Gorys Keraf, 2001). Perbendaharaan kata dalam bahasa Inggris perlu ditingkatkan dengan melatih pelafalan kosakata untuk meningkatkan ketrampilan berkomunikasi baik dalam merespon suatu pertanyaan dan juga percaya diri dalam memulai sebuah percakapan. Dengan demikian, pelafalan kosakata bahasa Inggris sangat penting dilatihkan kepada para siswa mempunyai motivasi dan kepercayaan diri dalam 3 berkomunikasi dengan bahasa Inggris sehingga siap menghadapi perkembangan jaman yang semakin pesat dengan segala keterbatasan yang dimiliki.

Para siswa di salah satu sekolah madrasah yang berlokasi di pontianak mempunyai kesulitan dalam belajar bahasa Inggris terutama dalam hal pelafalan kosakata yang sering dipelajari di sekolah. Pelafalan tidak diajarkan secara tersendiri atau spesifik di sekolah, karena target kurikulum dan hanya fokus pada ketrampilan menjawab soal untuk lulus UAS. Ketidaktahuan akan pelafalan yang tepat mengakibatkan multitafsir terhadap makna yang sebenarnya ingin disampaikan. Ketidakkonsistenan antara tulisan dan ucapan dan kurangnya latihan dalam melafalkannnya menyebabkan kesulitan dalam pelafalan dan komunikasi yang baik dalam bahasa Inggris.

Solusi yang ditawarkan adalah pendmpingan belajar tentang kosakata bahasa Inggris kepada para siswa SMP dengan menggunakan media scrabble. Scrabble adalah permainan stokastik yang dapat diamati sebagian Media scrabble memiliki keunggulan bahwa setiap pemain dalam permainan ini dituntut untuk memiliki perbendaharaan kata (Stuart \& Peter, 2003). Pengabdian ini menggunakan metode berupa pendampingan dan pembimbingan secara efektif dalam melafalkan kosakata dalam bahasa Inggris. Proses pelaksanaan pengabdian meliputi pembimbingan pelafalan kosakata dengan teknik pengenalan berbagai simbol simbol dalam tanda garis miring (Phonetics Transcription) dan pengenalan bunyi bunyi yang memiliki perbedaan yang sangat tipis sehingga sulit diinterpretasi ketika diucapkan oleh bukan penutur asli (non native speaker). Pelatihan juga dilakukan dengan metode pengulangan (drillling) dalam proses malafalkan bunyi kosakata dalam bahasa Inggris. Kemudian dilanjutkan dengan penggunaan pelafalan yang tepat dalam memproduksi sebuah kalimat atau 
ekspresi. Dengan demikian siswa mampu untuk meningkatkan ketrampilan berbahasa Inggris dengan baik dalam pelafalan kosakata.

\section{METODE}

Metode yang dilakukan dalam kegiatan pengabdian kepada masyrakat ini melalui pelatihan ini ada dua tahap kegiatan yaitu teoritik dan praktis (Muhtadi, 2011; Tilaar, 1992). Kegiatan yang bersifat teoritik ini dilakukan dengan menyampaikan materi tentang Scrabble serta penggunaannya dalam mengatasi permasalahan kosa kata di kelas. Pada tahap ini diawali dengan memberikan motivasi kepada peserta didik terkait pentingnya penggunaan scrabble dalam pembelajaran di kelas sehingga kegiatan belajar mengajar di kelas tidak monoton. Selain itu menjelaskan karakteristik tentang tata cara pengunaan permainan scrabble. Tahap kedua yaitu metode praktis yang mana peserta didik diajak bermain scrabble yang telah disampaikan sebelumnya. Kegiatan ini bertujuan untuk melatih keterampilan peserta didik dalam menggunakan permainan scrabble pada pembelajaran kosakata di kelas. Sebelumnya peserta didik telah diinformasikan untuk membawa alat bantu permainan seperti kamus elektronik maupun non elektronik, sehingga konsentrasi peserta didik dapat terfokus pada pencarian kosakata yang dianggap sulit.

Setelah melakukan latihan dalam menggunakan media pembelajaran scrabble, kemudian peserta didik mempresentasikan hasil nilai atau skor yang telah dicapai dan didiskusikan bersama perserta didik lainnya. Hal ini dilakukan untuk memberikan pengalaman langsung dan melatih keterampilan peserta didik secara langsung dalam menggunakan scrabble pada proses pembelajaran di kelas. Kegiatan ini dilakukan melalui proses pendampingan pada peserta kegiatan.. Berikut adalah desain metode kegiatan pendampingan ini dapat digambarkan dalam bentuk flow chat pada Gambar 1. 
Permasalahan Mitra

1. Pasifnya siswa di kelas

2. Keterbatasan media dalam belajar Bahasa Inggris

3. Kosakata siswa yang masih kurang/belum mumpuni

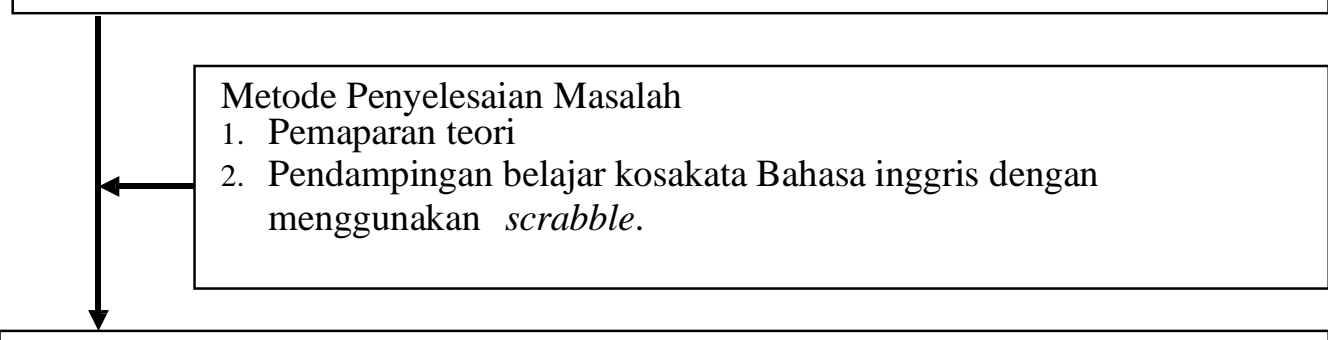

Solusi Permasalahan Mitra

1. Peningkatan antusias peserta didik dalam pembelajaran kosakata di kelas

2. Tercapainya peningkatan kosakata Bahasa Inggris

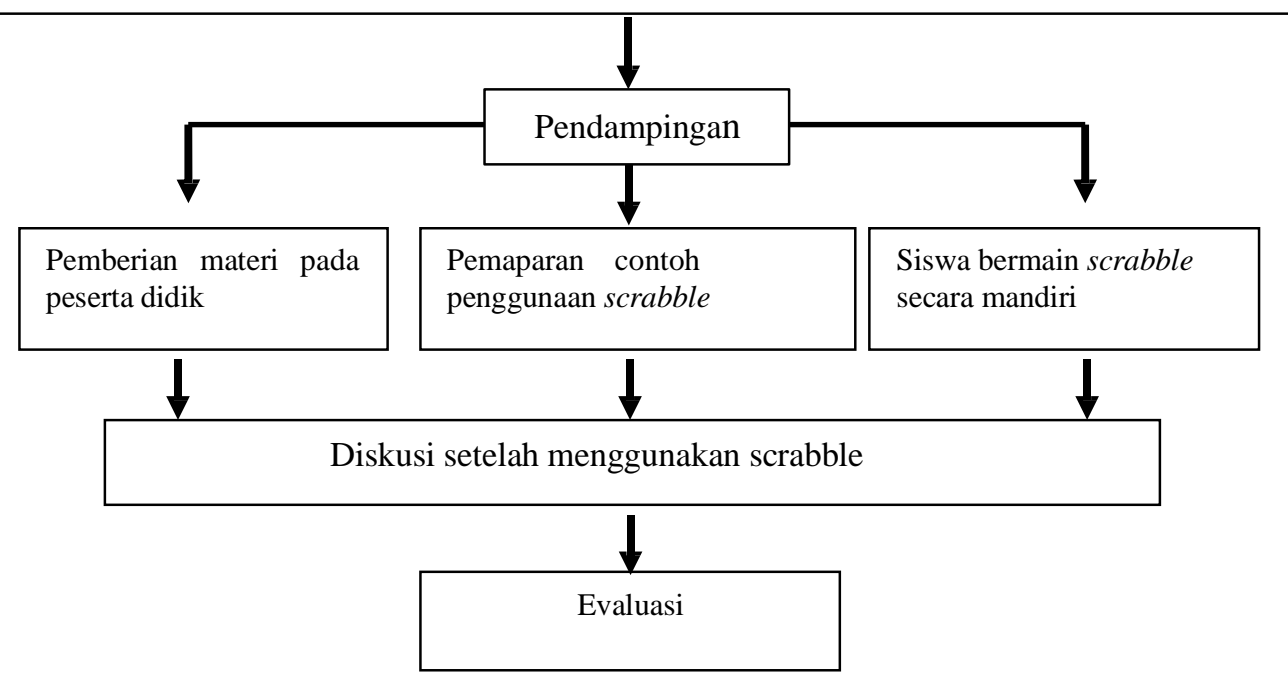

Gambar 1. Alur Kegiatan Pendampingan

\section{HASIL DAN PEMBAHASAN}

Peserta yang mengikuti kegiatan pelatihan ini merupakan siswi kelas VIII Madrasah Tsanawiyah Darunna'im yang berjumlah 35 orang. Pada hari pelaksanaan siswi yang hadir berjumlah 30 orang. Sebagian besar peserta merupakan santriwan dan santriwati yang tinggal di Pondok Pesantren Darunna'im. Sebagian kecilnya lagi merupakan siswa siswi yang berdomisili disekitar pesantren. Kegiatan diawali dengan acara pembukaan yang mencakup sambutan panitia pengabdian kepada masyarakat, sementara pembukaan secara resmi dilakukan oleh Kepala Sekolah. 


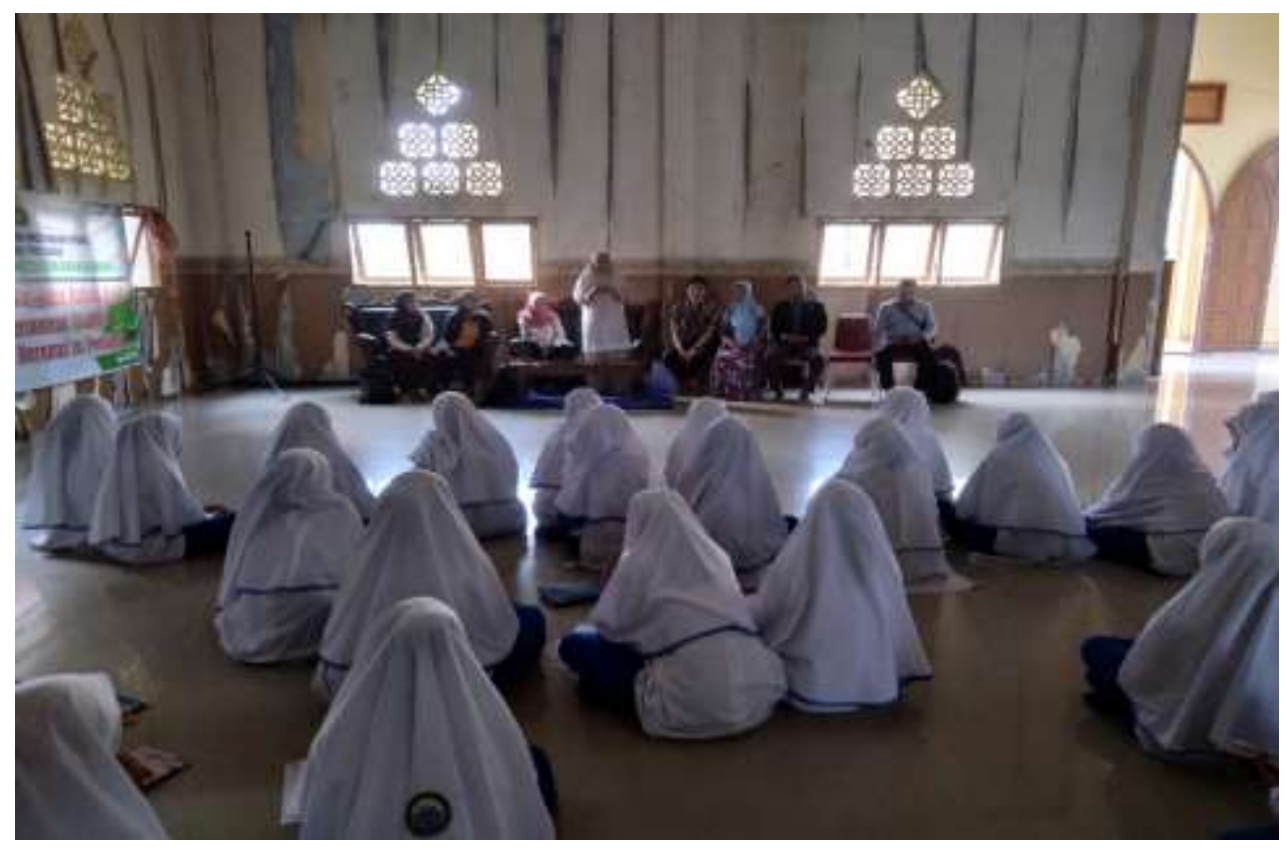

Gambar 2. Acara pembukaan

\section{Koordinasi dengan Pihak Sekolah}

Untuk keperluan kegiatan, Program Studi Pendidikan bahasa Inggris melalui Tim Panitia bekerja sama dengan MTS Darunna'im, yang beralamat di Darunna'im Jl. Ujung Pandang Pontianak. Dalam kerja sama ini pihak sekolah bertugas menyediakan peserta dan tempat pelaksanaan. Sementara pihak Prodi menyajikan materi, melakukan bimbingan, menyediakan konsumsi dan menerbitkan sertifikat pelatihan.

\section{Penyampaian Konsep Scrabble}

Narasumber menyampaikan materi tentang penggunaan permainan scrabble. Adapun konsep yang disampaikan adalah karakteristik dari permaian scrabble dan implementasi dalam pembelajaran di kelas. Dalam penyampaian materi ini terjadi respon yang positif dari peserta didik pelatihan ini. hal ini dapat ditunjukkan dengan beberapa peserta yang bertanya dan memberi tanggapan. Sebelum materi disajikan, narasumber bertanya kepada peserta, apa saja yang menjadi kendala kegiatan pembelajaran di kelas. Dari beberapa jawaban peserta dapat disimpulkan bahwa siswa ketika dikelas nampaknya memahami materi yang disampaikan, akan tetapi jika diberi soal atau pertanyaan tentang kosakata dasar Bahasa inggris pada diam tidak bisa menjawab. Hal tersebut menunjukkan peserta 
didik belum cukup mumpuni menguasai kosakata yang sederhana. Selain itu, narasumber juga bertanya, media pembelajaran apa saja yang digunakan selama ini di kelas. Mayoritas peserta menggunakan media pembelajaran langsung. Karena menurut peserta model tersebut yang mudah diterapkan di kelas.

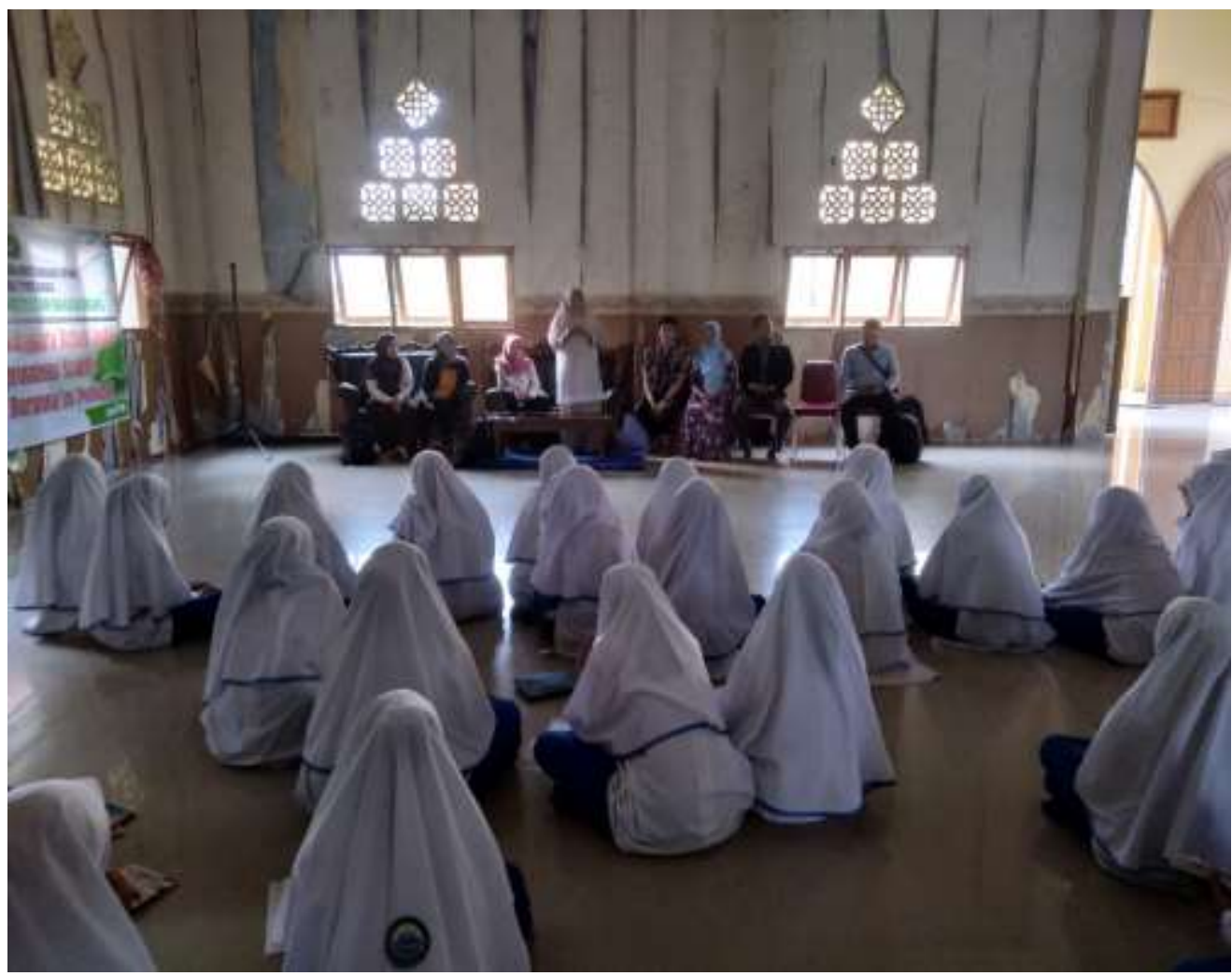

Gambar 3. Narsumber memberikan konsep tentang perbendaharaan kata

\section{Implementasi Permainan Scrabble}

Peserta dari pelatihan ini adalah para para siswa dan siswi kelas VIII MTS Darunna'im Pontianak. Narasumber menyampaikan materi atau konsep permainan scrabble menggunakan LCD. Adapun konsep yang disampaikan adalah karakteristik dari papan scrabble, dan implementasi dalam rencana perangkat pembelajaran. Dalam penyampaian materi ini terjadi respon yang positif dari peserta pelatihan ini. hal ini dapat ditunjukkan dengan beberapa peserta yang bertanya dan memberi tanggapan.

Sebelum materi disajikan, narasumber bertanya kepada peserta didik, apa saja yang menjadi kendala kegiatan pembelajaran di kelas. Dari beberapa jawaban peserta dapat disimpulkan bahwa peserta didik ketika dikelas nampaknya 
memahami materi yang disampaikan, akan tetapi jika diberi soal atau pertanyaan pada diam tidak bisa menjawab. Hal tersebut menunjukkan peserta didik tidak paham akan materi yang sudah disampaikan oleh guru, akibatnya hasil belajar rendah dan tujuan pembelajaran tidak tercapai. Selain itu, narasumber juga bertanya, model pembelajaran apa saja yang digunakan selama ini di kelas. Mayoritas peserta menggunakan model pembelajaran langsung. Karena menurut peserta model tersebut yang mudah diterapkan di kelas.

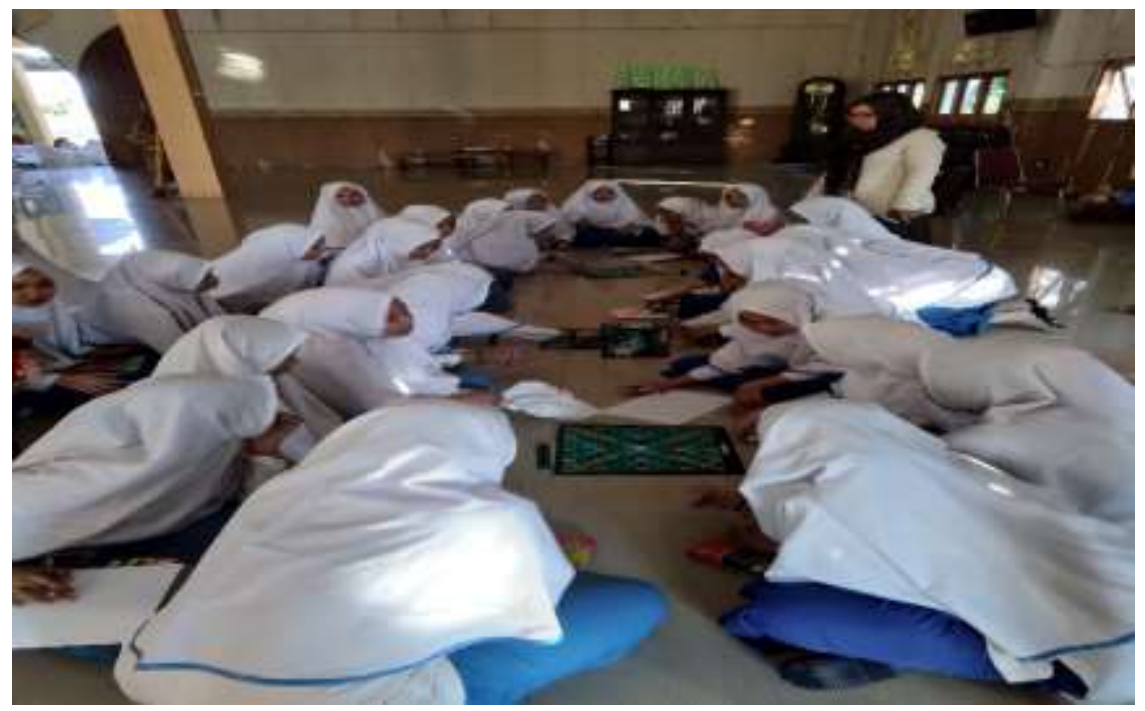

Gambar 3. Peserta didik memulai permaian scrabble

Pada hari ke 2 permainan dilanjutkan kembali. Pada pendampingan ini, proses pelaksanaan diatur sesuai dengan rencana yang telah ditetapkan sebelumnya. Pertama adalah membuka pelatihan dengan greeting yang sudah dipelajari pada pelatihan pertama, kemudian pengabdi mengecek apakah siswa sudah merespon dengan tepat. Apabila ada peserta yang masih kurang tepat dalam melafalkan maka pengabdi wajib memberikan koreksi. Pada pelatihan sebelumnya peserta di berikan tugas untuk mencari dan berlatih mengucapkan kosakata. Selanjutnya, pengabdi memberikan tanggapan dan menggarisbawahi beberapa pelafalan yang perlu dibenarkan. Dengan demikian para peserta dapat mengetahui ketepatan dan kesesuaian sebuah pelafalan kosakata yang sesuai.

Peserta diberikan latihan, yaitu mengisi kalimat rumpang dengan mendengarkan sebuah dialog atau percakapan dari audio tentang materi yang telah dijelaskan. Semua peserta tampak antusias dalam mengerjakan dan mendengarkan 
audio yang diputar sambil kadang kadang ada yang ikut menirukan pengucapan yang mereka dengar. 11 Setelah sekitar 10 menit, peserta selesai mengerjakan soal yang diberikan, kemudain setelah itu dibahas bersama sama. Semua memberikan pendapat masing masing dalam menjawab soal. Diskusi pun tercipta pada saat ada jawaban yang tidak sama. Kemudian peserta diminta untuk mempraktekan ke depan dengang bermain peran sesuai dengan dialog atau percakapan yang telah mereka selesaikan sebelumnya. Proses dialog berjalan dengan baik. Ada beberapa peserta yang sempurna melakukan dialog yang diminta.

\section{Faktor Pendukung Pelatihan}

Beberapa faktor pendukung terlaksana nya pelatihan ini adalah Kepala sekolah di sekolah mitra yaitu Madrasah Tsanawiyah Darunna'im Pontianak sangat mendukung pelatihan ini berlangsung dengan menyediakan tempat pelaksanaan dan peserta pelatihan. Selain itu antusiasme peserta didik dalam mengikuti pendampingan dan menerapkan media pembelajaran yang telah mereka dapatkan di kelas.

\section{Kendala dalam Pelatihan}

Kendala dalam pelatihan ini meliputi keterbatasan waktu yang diberikan oleh pihak sekolah, sehingga belum dapat terlaksana nya follow up dari hasil implementasi permainan scrabble di kelas, karena aktivitas kegiatan di sekolah dan kurangnya tersedia nya media dalam hal ini LCD di dalam setiap kelas, sehingga tidak semua peserta didik belajar menggunakan media power point.

\section{SIMPULAN}

Proses pelatihan dalam pengabdian ini dilakukan dengan menggunakan dan mengaplikasikan media sebagai alat untuk memudahkan anak dalam belajar dan membuat proses belajar dalam pelatihan lebih menarik dan interaktif. Media pembelajaran berfungsi untuk meningkatkan motivasi siswa, mencegah kebosanan siswa dalam mengikuti suatu proses pembelajaran dan memperkuat pemahaman siswa dalam konteks yang nyata. Melalui sebuah proses penggunaan media, penguasaan strategi pemilihan yang tepat, dan penggunaan secara kreatif dalam kemasan tindakan yang variatif, kompetensi anak akan semakin meningkat. 
Pelafalan kosakata perlu diajarkan pada anak didik sedini mungkin untuk meminimalisir kesalahan pengucapan dan meningkatkan ketrampilan berbicara untuk mendukung ketrampilan berkomunikasi dalam bahasa Inggris dengan lebih baik. Penggunaan media dalam belajar sangatlah penting untuk memfasilitasi siswa dalam mempelajari materi dan untuk menciptakan situasi belajar yang menarik dan menyenangkan sehinggaa motivasi siswa meningkat.

\section{DAFTAR PUSTAKA}

Prince, M., \& Felder, R. (2000). The many faces of inductive teaching and learning. Journal of college science teaching, 36 (5), 14.

Gorys, K, D. (2001). Diksi dan gaya bahasa. Gramedia Pustaka Utama.

Mukoroli, J. (2011). Effective vocabulary teaching strategies for the English for academic purposes ESL Classroom. MA TESOL Collection. Paper 501/online.

Muhtadi, A. (2011). Pendidikan Dan Pembelajaran Di Sekolah Rumah (Home Schooling): Suatu tinjauan teoritis dan praktis. Majalah Ilmiah Pembelajaran.

Schmitt, N., \& Schmitt, D. (2014). A reassessment of frequency and vocabulary size in L2 vocabulary teaching. Language Teaching, 47: 484-503.

Stuart, R., \& Peter, N. (2003). Artificial intelligence: a modern approach.

Tilaar, H. A. R. (1992). Manajemen pendidikan nasional: kajian pendidikan masa depan. Remaja Rosdakarya. 